\title{
Desert dust outbreaks and respiratory morbidity in Athens, Greece
}

\author{
Stavroula-Myrto Trianti ${ }^{*}$, Evangelia Samoli ${ }^{2}$, Sophia Rodopoulou² ${ }^{2}$ Klea Katsouyanni², Spyros A. Papiris ${ }^{1}$ \\ and Anna Karakatsani ${ }^{1}$
}

\begin{abstract}
Background: Ambient particulate matter (PM) has an adverse effect on respiratory morbidity. Desert dust outbreaks contribute to increased PM levels but the toxicity of desert dust mixed with anthropogenic pollutants needs clarification.

Methods: We identified 132 days with desert dust episodes and 177 matched days by day of the week, season, temperature and humidity between 2001 and 2006 in Athens, Greece. We collected data on regulated pollutants and daily emergency outpatient visits and admissions for respiratory causes. We applied Poisson regression models adjusting for confounding effects of seasonality, meteorology, holidays and influenza epidemics. We evaluated the sensitivity of our results to co-pollutant exposures and effect modification by age and sex.

Results: A $10 \mu \mathrm{g} / \mathrm{m}^{3}$ increase in $\mathrm{PM}_{10}$ concentration was associated with 1.95\% (95\% confidence interval (Cl): $0.02 \%, 3.91 \%)$ increase in respiratory emergency room visits. No significant interaction with desert dust episodes was observed. Compared with non-dust days, there was a 47\% (95\% Cl: 29\%, 68\%) increase in visits in dust days not adjusting for $\mathrm{PM}_{10}$. Desert dust days were associated with higher numbers of emergency room visits for asthma, chronic obstructive pulmonary disease and respiratory infections with increases of 38\%, $57 \%$ and $60 \%$, respectively ( $p<0.001$ for all comparisons). Analyses of respiratory hospital admissions provided similar results. $\mathrm{PM}_{10}$ effects decreased when adjusting for desert dust days and were further confounded by co-pollutants.
\end{abstract}

Conclusions: Desert dust episode days are associated with higher respiratory emergency room visits and hospital admissions. This effect is insufficiently explained by increased $\mathrm{PM}_{10}$ levels.

Keywords: Desert dust, Particulate matter, $\mathrm{PM}_{10}$, Respiratory morbidity

\section{Background}

Transportation of desert dust, originating mainly from Sahara, is common in Europe, especially in the Mediterranean countries, resulting to increased concentrations of ambient particles with a median aerodynamic diameter $<10 \mu \mathrm{m}\left(\mathrm{PM}_{10}\right)$ [1-4]. $\mathrm{PM}_{10}$ is a mixture of coarse $\left(2.5-10 \mu \mathrm{m}, \mathrm{PM}_{2.5-10}\right)$, fine $\left(<2.5 \mu \mathrm{m}, \mathrm{PM}_{2.5}\right)$ and ultrafine $\left(<0.1 \mu \mathrm{m}, \mathrm{PM}_{0.1}\right)$ particles generated from different processes, having variable chemical composition and atmospheric behavior. The adverse health effects of shortterm exposures to $\mathrm{PM}_{10}$ and $\mathrm{PM}_{2.5}$ have been well documented during the last decades whilst from recent studies

\footnotetext{
* Correspondence: myrtotrianti@yahoo.gr

2nd Department of Pulmonary Medicine, School of Medicine, National and Kapodistrian University of Athens, "ATTIKON" University Hospital, Athens, Greece

Full list of author information is available at the end of the article
}

there is increasing evidence that the health effects of coarse particles should not be underestimated [5-8].

Recent evidence has shown that desert dust outbreaks alter particle size distribution as well as their chemical composition [9-12]. This effect depends on several factors such as the dust origin as well as the transportation route until the dust reaches the particular destination. Previous studies have indicated an increase in crustal elements of $\mathrm{PM}_{2.5}$ in dust days compared with non-dust days as well as differences in the concentrations of selected metals of larger particles [13]. Additionally, there is evidence for a microbial component of the transported dust [14]. However, from the limited number of studies carried out to establish the health effects due to the desert dust source, there are conflicting results [15]. 
The Athens area in Greece, with a population over 4 million inhabitants, faces a serious air pollution problem that has existed for more than 30 years. Its topography, a basin surrounded by mountains in the north, east and northwest and by the sea on the southwest side, favours atmospheric inversion and high pollutants' concentrations. Previous studies have shown effects of air pollution on respiratory mortality and morbidity in the Greater Athens area [16-18].

Desert dust events generally occur about 30 days per year in Athens, mainly between spring and autumn [19]. Most such events originate from Sahara but there are a few days when they originate from the Arabian Peninsula. Previous studies on the health effects of desert dust episodes in Athens indicated that effects on mortality outcomes [20] could not be sufficiently captured by PM levels while they were associated with an increase in pediatric asthma admissions [21].

The rather limited evidence warrants further investigation as determining the possible effects of exposure to desert dust particles may be directly linked to policy decisions. In the present study, to further clarify the potential toxicity of desert dust mixed with anthropogenic pollutants, we investigated the effect of desert dust events on respiratory morbidity in the Southern Mediterranean metropolitan region of Athens, Greece.

\section{Methods}

Between 2001 and 2006, we identified 132 days with desert dust episodes, in Athens, Greece, using backtrajectory analysis (to locate air mass transport) in combination with a data driven criterion, based on high particle concentrations provided by the fixed monitoring sites [20]. In brief, a day was defined as one with dust event if air mass transport, identified through the backtrajectories maps, had occurred from the Sahara or the Arabian Peninsula and the ratio of the $\mathrm{PM}_{10}$ concentration measured at a suburban monitor located at the outskirts of the Athens north region to an urban monitor in the center of the town exceeded the median of this ratio during that year.

During the same time period, we selected 177 control days fulfilling the following criteria: same day of the week and same season with the desert dust day as well as similar meteorological data, i.e. the desert dust and control day should not differ in mean temperature and humidity by no more than $2^{\circ} \mathrm{C}$ and $7 \%$, respectively. Same season was defined as the same season within the same calendar year with exception of the winter which extended from December of a given year to February of the next year.

Daily air pollution concentrations were provided by the monitoring network operated by the Ministry of Environment, Energy and Climate Change (www.ypeka.gr): for
$\mathrm{PM}_{10}$ and $\mathrm{NO}_{2}$ daily $24 \mathrm{~h}$ average data, for $\mathrm{O}_{3}$ daily $8 \mathrm{~h}$ maximum data.

Daily data of emergency outpatient visits and admissions for respiratory causes of adult patients were recorded from 1st January 2001 to 31th December 2006 for the days that were identified as days with desert dust events as well as for the control days in 16 out of 19 pulmonary departments (84\%) participating in the emergency services network of the Athens' Metropolitan Area. The collection of data was performed retrospectively by reviewing the respective hospital records that provide a complete and consecutive registration of all emergency room visits and admissions. Exclusion criteria included: a) scheduled hospital admissions during the specific days, b) emergency room visits of patients who were transferred to hospitals outside the larger Athens area (Attica) or who were not residents of Athens, c) emergency room visits, for which the symptoms were attributed to tuberculosis, neoplastic diseases, aspiration pneumonia, accidental inhalation of smoke or toxic gases, fever or chest pain of nonrespiratory origin and cases with prolonged symptoms. In all registered cases, the following parameters were recorded: date of visit, age, gender, final diagnosis, and outcome defined as discharge directly from the emergency room, hospital admission, or death in the emergency room.

Due to the lack of electronic records for emergency room visits and relevant data, such as demographics, diagnostics, performed examinations and outcome (i.e. discharge or admission, recommendations to the patient etc), all data analyzed for the present work were collected manually by reviewing the emergency department books kept in the hospitals' archives for the a-priori defined desert dusts days and their matched control days during the study period.

Medical ethical clearance was acquired from the institutional review boards of all involved hospitals.

We applied Poisson regression models adjusting for any remaining confounding effects of seasonality and long term trends using a two way interaction between year and month. For both $\mathrm{PM}_{10}$ and for dust events we used lag 0 as an a-priori choice. We controlled for meteorology using a natural spline with 3 degrees of freedom for mean daily temperature and a linear term for relative humidity. We also included indicator variables for day of the week, holidays and influenza epidemics.

We evaluated the sensitivity of our results to copollutant exposures and effect modification by age (below and above 65 years) and sex. We furthermore excluded events for which we estimated the age in the age stratified analysis. Finally, we assessed robustness by using the approach adopted by the MED-PARTICLES project to characterize a day as desert dust or not (within the sample of days with available health data in 
our analysis) [22]. In brief, MED-PARTICLES investigators have used a variety of tools (meteorological products, aerosol maps, back trajectories, satellite images and the reference to identify dust transport and supplied us with their characterization upon our request.

As additional sensitivity analyses, we applied two modelling approaches that preserved the matching of "dust" and "non-dust" days but use more degrees of freedom in the models. In the first approach, we added 132 indicators for the matched sets and in the second approach, we applied a mixed Poisson model with a random intercept for matched sets of days.

\section{Results}

The distribution of daily meteorological and air pollution data as well as the daily number of emergency outpatient visits and admissions for respiratory causes stratified by desert dust and matching control days are presented in Table 1.

The distribution of days with desert dust events by season and year, presented in Table 2, reveals that dust episodes tend to occur on spring (31.1\% of dust days) or fall ( $28 \%$ of dust days) that is periods with lower pollution in general. Over the 6 years of the examined period,
Table 2 Distribution of days (number and percent) with desert dust events by season and year

\begin{tabular}{lll}
\hline Season & Winter & $33(25.0)$ \\
& Spring & $41(31.1)$ \\
Summer & $21(15.9)$ \\
Fall & $37(28.0)$ \\
Year & 2001 & $32(24.2)$ \\
& 2002 & $31(23.5)$ \\
2003 & $15(11.4)$ \\
2004 & $26(19.7)$ \\
2005 & $13(9.9)$ \\
2006 & $15(11.4)$ \\
\hline
\end{tabular}

there were differences in the yearly distribution with highest occurrence of events in 2001, 2002 and 2004 and considerably less dust events in the other years.

During the study period, a total of 13,685 emergency room visits (47\% females) were recorded. Out of these, 4213 patients were admitted for further management whilst 10 died in the emergency room. For 4 patients, information on the outcome was missing. For 1929 visits (14\%) the patient's age was not available, these missing

Table 1 Distribution of pollution and meteorological data and daily respiratory emergency room visits and hospital admissions during dust and control days as well as pollution and meteorological data for the whole 6-year period

\begin{tabular}{|c|c|c|c|}
\hline & $\begin{array}{l}\text { Desert dust } \\
\text { days } \\
N=132\end{array}$ & $\begin{array}{l}\text { Control days } \\
N=177\end{array}$ & $\begin{array}{l}\text { Whole period } \\
\text { 2001-2006 }\end{array}$ \\
\hline \multicolumn{4}{|l|}{$\begin{array}{l}\text { Pollution data in } \mu \mathrm{g} / \mathrm{m}^{3} \\
\text { (median (25th-75th percentile)) }\end{array}$} \\
\hline $\mathrm{PM}_{10}$ & $45.9(36.5-78.5)$ & $44.0(34.6-54.2)$ & $39.6(30.7-50.8)$ \\
\hline $\mathrm{SO}_{2}$ & $10.3(6.8-16.4)$ & $13.8(9.0-20.3)$ & $13.0(7.9-20.6)$ \\
\hline $\mathrm{NO}_{2}$ & $40.3(32.0-48.9)$ & $48.0(39.7-60.4)$ & $44.2(34.8-54.6)$ \\
\hline $\mathrm{O}_{3}$ & $61.8(46.5-72.4)$ & $71.7(51.4-90.9)$ & $68.7(47.5-90.2)$ \\
\hline \multicolumn{4}{|c|}{ Meteorological data (mean (standard deviation)) } \\
\hline Temperature $\left({ }^{\circ} \mathrm{C}\right)$ & $18.9(5.2)$ & $19.1(5.9)$ & $18.0(12.4-24.8)$ \\
\hline Relative humidity (\%) & $69.1(14.8)$ & $67.1(14.4)$ & $67.1(56.0-76.9)$ \\
\hline \multicolumn{4}{|l|}{$\begin{array}{l}\text { Number of daily emergency room visits } \\
\text { (median (25th-75th percentile)) }\end{array}$} \\
\hline Total visits per day & $50(35-68)$ & $38(25-47)$ & \\
\hline Male patients & $27(19-35)$ & $19(12-25)$ & \\
\hline Female patients & $23(15-32)$ & $17(12-23)$ & \\
\hline Age $18-64$ years & $30(19-39)$ & $22(14-27)$ & \\
\hline Age $\geq 65$ years & $20(13-29)$ & $16(10-21)$ & \\
\hline Total hospital admissions per day & $15(10-22)$ & $12(6-16)$ & \\
\hline Male patients & $8(5-13)$ & $7(4-10)$ & \\
\hline Female patients & $5(3-9)$ & $4(2-7)$ & \\
\hline Age $18-64$ years & $5(3-8)$ & $4(2-6)$ & \\
\hline Age $\geq 65$ years & $9(6-14)$ & $8(4-11)$ & \\
\hline
\end{tabular}


values were replaced by the mean age of patients with the same diagnosis.

Table 3 presents the estimated effects of desert dust events and $\mathrm{PM}_{10}$ concentrations on the numbers of emergency room visits for respiratory causes, stratified by gender, age group (below or above 65 years) and diagnoses (asthma, chronic obstructive pulmonary disease [COPD], respiratory infections). The effect estimates of either dust episodes or $\mathrm{PM}_{10}$ were statistically significant when individually introduced in the model. There was a $47 \%$ (95\% confidence interval (CI) 28.65\%-68.19\%; $p<0.001$ ) increase in the total number of emergency room visits during desert dust versus non-dust days, not adjusting for $\mathrm{PM}_{10}$. No effect modification was observed by gender or age group. With respect to specific respiratory diagnoses, desert dust days were associated with higher numbers of emergency room visits for asthma, COPD and respiratory infections with increases of 38,57 and $60 \%$, respectively (for all, $p<0.001$ ). Furthermore, a $10 \mu \mathrm{g} / \mathrm{m}^{3}$ increase in the $\mathrm{PM}_{10}$ concentration was associated with $1.95 \%$ (95\% CI: $0.02 \%, 3.91 \% ; p=0.05$ ) increase in total respiratory emergency room visits, not adjusting for desert dust events or other air pollutants. This effect was more pronounced among males and in patients older than 65 years [2.2\% $(p=0.03)$ and $2.1 \%(p=0.05)$ increase for a $10 \mu \mathrm{g} /$ $\mathrm{m}^{3} \mathrm{PM}_{10}$ increase, respectively). As for specific respiratory diagnoses, $\mathrm{PM}_{10}$ concentrations were significantly associated with increased numbers of emergency room visits for COPD but not for asthma or respiratory infections.

The estimated adverse desert dust effects on respiratory morbidity were robust to adjustment to $\mathrm{PM}_{10}$, while particles' effects were confounded by the inclusion of the dust indicator but retaining the adverse association (Table 3).

Table 4 presents the percent increase and 95\% CI of daily respiratory hospital admissions associated with desert dust events and a $10 \mu \mathrm{g} / \mathrm{m}^{3}$ increase in $\mathrm{PM}_{10}$ concentrations. The pattern observed in all outcomes analyzed was the same as the one observed for daily emergency room visits during desert dust episodes versus non desert dust days. Similarly to the effect on emergency room visits, the particles' effects retained their adverse association when the dust indicator was included in the model. This pattern was observed in both male and female patients as well in younger and older patients.

We also allowed for an interaction term between $\mathrm{PM}_{10}$ and desert dust events in our models. There was not statistically significant interaction for any of the associations under investigation.

As shown in Table 5, our estimates were robust to the alternative inclusion of $\mathrm{NO}_{2}$ or $\mathrm{O}_{3}$ into our model. The effect estimate of desert dust events on all respiratory emergency room visits or on hospital admissions remained highly significant ( $p<0.001$ for all analyses) whereas the $\mathrm{PM}_{10}$ concentrations had no significant effect on these health outcomes in the mutually adjusted model. Additional file 1: Table S1 provides the effect estimates for the association between gaseous pollutants and respiratory morbidity.

After applying the criteria used in the MEDPARTICLES project to redefine days as either "a desert dust day" or "not a desert dust day", the days with common characterization we ended up, were 81 dust days and 110 control (non-dust) days. In sensitivity analyses, the direction as well as the magnitude of the effects remained robust when we included only the days with common characterization based on both approaches (Additional file 1: Table S2).

Results from the sensitivity analysis in the subgroup of patients with complete information on their age provided similar results both in the magnitude of the effects and in the statistical significance. For example, the percent change in emergency room visits for respiratory causes in the mutually adjusted model for those 18-64 years was

Table 3 Percent increase and 95\% confidence interval (in parentheses) of daily respiratory emergency room visits associated with $10 \mu \mathrm{g} / \mathrm{m}^{3}$ increase in $\mathrm{PM}_{10}$ levels and occurrence of desert dust event

\begin{tabular}{|c|c|c|c|c|c|c|c|c|}
\hline \multirow[t]{3}{*}{ Emergency Room Visits } & \multicolumn{4}{|c|}{ Individually in the model } & \multicolumn{4}{|l|}{ Mutually Adjusted } \\
\hline & \multicolumn{2}{|c|}{$\mathrm{PM}_{10}\left(\right.$ per $\left.10 \mu \mathrm{g} / \mathrm{m}^{3}\right)$} & \multicolumn{2}{|c|}{ Dust Day (Yes vs No) } & \multicolumn{2}{|c|}{$\mathrm{PM}_{10}\left(\right.$ per $\left.10 \mu \mathrm{g} / \mathrm{m}^{3}\right)$} & \multicolumn{2}{|l|}{ Dust Day (Yes vs No) } \\
\hline & $\%(95 \% \mathrm{Cl})$ & $P$-value & $\%(95 \% \mathrm{Cl})$ & $P$-value & $\%(95 \% \mathrm{Cl})$ & $P$-value & $\%(95 \% \mathrm{Cl})$ & $P$-value \\
\hline All respiratory & $1.95(0.02,3.91)$ & 0.05 & $47.09(28.65,68.19)$ & $<0.001$ & $0.99(-0.88,2.89)$ & 0.30 & $45.25(26.75,66.45)$ & $<0.001$ \\
\hline Male & $2.17(0.18,4.2)$ & 0.03 & $45.91(26.7,68.03)$ & $<0.001$ & $1.25(-0.7,3.24)$ & 0.21 & $43.60(24.42,65.73)$ & $<0.001$ \\
\hline Female & $1.81(-0.26,3.93)$ & 0.09 & $45.81(26.38,68.24)$ & $<0.001$ & $0.86(-1.16,2.91)$ & 0.41 & $44.22(24.66,66.86)$ & $<0.001$ \\
\hline 18-64 years & $1.86(-0.16,3.92)$ & 0.07 & $49.09(29.64,71.45)$ & $<0.001$ & $0.88(-1.08,2.88)$ & 0.38 & $47.46(27.93,69.99)$ & $<0.001$ \\
\hline$\geq 65$ years & $2.07(-0.01,4.19)$ & 0.05 & $44.34(24.65,67.13)$ & $<0.001$ & $1.14(-0.89,3.22)$ & 0.27 & $42.17(22.46,65.07)$ & $<0.001$ \\
\hline Asthma (J45) & $1.98(-0.41,4.42)$ & 0.11 & $38.37(16.84,63.85)$ & $<0.001$ & $1.17(-1.21,3.61)$ & 0.34 & $36.33(14.79,61.91)$ & $<0.001$ \\
\hline COPD (J44) & $3.21(0.9,5.58)$ & 0.007 & $57.14(33.22,85.35)$ & $<0.001$ & $2.11(-0.15,4.42)$ & 0.07 & $52.91(29.35,80.75)$ & $<0.001$ \\
\hline Respiratory infections (J06) & $1.17(-1.32,3.71)$ & 0.36 & $60.43(35.37,90.13)$ & $<0.001$ & $-0.03(-2.45,2.45)$ & 0.98 & $60.49(35.02,90.77)$ & $<0.001$ \\
\hline
\end{tabular}


Table 4 Percent increase and 95\% confidence intervals (CI) of daily numbers of admissions (including deaths) due to respiratory emergency visits associated with $10 \mu \mathrm{g} / \mathrm{m}^{3}$ increase in $\mathrm{PM}_{10}$ levels and occurrence of desert dust event

\begin{tabular}{|c|c|c|c|c|c|c|c|c|}
\hline \multirow[t]{3}{*}{ Admissions } & \multicolumn{4}{|c|}{ Individually in the model } & \multicolumn{4}{|l|}{ Mutually Adjusted } \\
\hline & \multicolumn{2}{|c|}{$\mathrm{PM}_{10}\left(\right.$ per $\left.10 \mu \mathrm{g} / \mathrm{m}^{3}\right)$} & \multicolumn{2}{|c|}{ Dust Day (Yes vs No) } & \multicolumn{2}{|c|}{$\mathrm{PM}_{10}\left(\right.$ per $\left.10 \mu \mathrm{g} / \mathrm{m}^{3}\right)$} & \multicolumn{2}{|c|}{ Dust Day (Yes vs No) } \\
\hline & $\%(95 \% \mathrm{Cl})$ & $P$-value & $\%(95 \% \mathrm{Cl})$ & $P$-value & $\%(95 \% \mathrm{Cl})$ & $P$-value & $\%(95 \% \mathrm{Cl})$ & $P$-value \\
\hline All respiratory & $1.60(-0.69,3.95)$ & 0.17 & $40.68(20.23,64.61)$ & $<0.001$ & $0.70(-1.57,3.03)$ & 0.55 & $39.44(18.82,63.64)$ & $<0.001$ \\
\hline Male & $1.92(-0.58,4.47)$ & 0.14 & $41.71(19.09,68.63)$ & $<0.001$ & $1.04(-1.46,3.59)$ & 0.42 & $39.9(17.22,66.98)$ & $<0.001$ \\
\hline Female & $1.26(-1.33,3.93)$ & 0.34 & $38.52(16.03,65.37)$ & $<0.001$ & $0.36(-2.23,3.01)$ & 0.79 & $37.87(15.05,65.21)$ & $<0.001$ \\
\hline $18-64$ years & $1.63(-1.3,4.65)$ & 0.28 & $41.1(15.57,72.27)$ & 0.001 & $0.70(-2.25,3.73)$ & 0.65 & $39.87(14.13,71.43)$ & $<0.001$ \\
\hline$>65$ years & $1.59(-0.75,3.99)$ & 0.19 & $40.39(19.35,65.14)$ & $<0.001$ & $0.71(-1.62,3.09)$ & 0.55 & $39.13(17.92,64.17)$ & $<0.001$ \\
\hline
\end{tabular}

0.53\% (95\% CI: $-1.48 \%, 2.58 \%)$ per $10 \mu \mathrm{g} / \mathrm{m}^{3}$ increase in $\mathrm{PM}_{10}$ and $53.20 \%$ (95\% CI: $32.56 \%, 77.06 \%$ ) for the dust indicator; for those $\geq 65$ years the corresponding estimates were $0.51 \%$ (95\% CI: $-1.67 \%, 2.74 \%)$ and $46.19 \%$ (95\% CI: $24.88 \%, 71.14 \%)$. The results from the additional sensitivity analysis models applied did not substantially change the main findings (Additional file 1: Tables S3 and S4).

\section{Discussion}

Our results support that desert dust transportation affects respiratory morbidity in Athens, Greece, as we observed associated increases in respiratory emergency room visits and hospital admissions for respiratory reasons. Interestingly, this effect does not seem to be at least sufficiently explained by increased $\mathrm{PM}_{10}$ levels.

Desert dust outbreaks are frequent over the Mediterranean basin and may be directly linked to policy decisions as they contribute significantly to the burden of atmospheric mineral dust and to $\mathrm{PM}_{10}$ concentrations exceeding the daily recommended limits $[1-4,19,23]$. Desert dust consists of coarse particles which have been associated mainly with respiratory outcomes. Recent epidemiological and toxicological studies indicate that the health effects of coarse particles should not be underestimated and that their levels should be regulated along with those of fine particles $[7,8,24]$.

Thus, for reasons of public health protection, it is of great importance to clarify potential adverse health effects of desert dust outbreaks. So far, studies on the health effects of such outbreaks or on their modifying role in particulate matter health effects are limited and have reported contradictory results [15].

Studies focusing on the effect of desert dust outbreaks on mortality that were conducted in the Mediterranean and particularly in Spain $[13,25]$ and Italy $[26,27]$ provided evidence for an independent association between such events and daily mortality. They indicated a stronger effect of coarse particles and $\mathrm{PM}_{10}$ on mortality during dust days but also an increased effect on the elderly [28]. In contrast, Samoli et al. [20] did not report effect

Table 5 Percent increase and 95\% confidence intervals $(\mathrm{Cl})$ of daily respiratory emergency room visits and hospital admissions associated with $10 \mathrm{\mu g} / \mathrm{m}^{3}$ increase in $\mathrm{PM}_{10}$ levels and occurrence of desert dust event. Results from two pollutants' models

\begin{tabular}{|c|c|c|c|c|}
\hline \multirow[b]{2}{*}{ Respiratory Health Outcomes } & \multicolumn{2}{|c|}{ Individually in the model } & \multicolumn{2}{|l|}{ Mutually Adjusted } \\
\hline & $\%(95 \% \mathrm{Cl})$ & $P$-value & $\%(95 \% \mathrm{Cl})$ & $P$-value \\
\hline \multicolumn{5}{|l|}{ All emergency room visits } \\
\hline \multicolumn{5}{|l|}{ Adjusted for $\mathrm{NO}_{2}$} \\
\hline $\mathrm{PM}_{10}\left(\right.$ per $\left.10 \mu \mathrm{g} / \mathrm{m}^{3}\right)$ & $1.93(0.065,3.84)$ & 0.04 & $1.04(-0.83,2.94)$ & 0.28 \\
\hline Dust Day (Yes vs No) & $44.78(25.34,67.25)$ & $<0.001$ & $42.50(23.00,65.09)$ & $<0.001$ \\
\hline \multicolumn{5}{|l|}{ Adjusted for $\mathrm{O}_{3}$} \\
\hline $\mathrm{PM}_{10}\left(\right.$ per $10 \mu \mathrm{g} / \mathrm{m}^{3}$ ) & $2.03(0.09,4.01)$ & 0.04 & $1.15(-0.71,3.05)$ & 0.23 \\
\hline Dust Day (Yes vs No) & $50.20(31.09,72.10)$ & $<0.001$ & $48.25(29.18,70.14)$ & $<0.001$ \\
\hline \multicolumn{5}{|l|}{ All admissions } \\
\hline \multicolumn{5}{|l|}{ Adjusted for $\mathrm{NO}_{2}$} \\
\hline $\mathrm{PM}_{10}\left(\right.$ per $\left.10 \mu \mathrm{g} / \mathrm{m}^{3}\right)$ & $1.62(-0.62,3.91)$ & 0.16 & $0.75(-1.54,3.08)$ & 0.53 \\
\hline Dust Day (Yes vs No) & $39.19(17.40,65.04)$ & $<0.001$ & $37.59(15.78,63.79)$ & $<0.001$ \\
\hline \multicolumn{5}{|l|}{ Adjusted for $\mathrm{O}_{3}$} \\
\hline $\mathrm{PM}_{10}\left(\right.$ per $\left.10 \mu \mathrm{g} / \mathrm{m}^{3}\right)$ & $1.73(-0.58,4.09)$ & 0.14 & $0.90(-1.37,3.22)$ & 0.44 \\
\hline Dust Day (Yes vs No) & $43.90(22.69,68.78)$ & $<0.001$ & $42.45(21.18,67.45)$ & $<0.001$ \\
\hline
\end{tabular}


modification of $\mathrm{PM}_{10}$ effects on mortality in Athens, Greece by desert dust. Similarly, in a project conducted in multiple Mediterranean areas, $\mathrm{PM}_{10}$ concentrations originating from desert dust and those from other sources were both associated with mortality [22].

In our study, we focused on the effect of desert dust outbreaks and on the potential modifying effect on $\mathrm{PM}_{10}$ effects particularly on respiratory morbidity. We consider the focus on respiratory morbidity a major advantage of our study due to the plausible biological explanation. The respiratory system belongs to the systems of the human body, for which there is convincing evidence for a significant influence exerted by meteorological and atmospheric conditions and an associated effect on morbidity [29-31]. Thus, it seems plausible that adverse effects of an increased pollution burden and of altered atmospheric conditions due to desert dust outbreaks would manifest predominantly in the respiratory system. Indeed, several mechanisms for an adverse effect of particulate matter on the respiratory system have been proposed including for instance local inflammatory reaction [32], the induction of a systemic inflammatory response augmenting lung inflammation [33], or cytotoxicity and oxidative damage $[34,35]$. Furthermore and to the best of our knowledge, this is the first study that addresses the effects of desert dust events on respiratory emergency room visits apart from admissions and also investigates associations with specific respiratory diseases.

Our results are in general consistent with other morbidity studies from the Mediterranean. Middleton et al. observed an increased hospitalization risk particularly for cardiovascular causes on dust storm days in Cyprus [36]. Similarly, Samoli et al. reported more emergency hospital admissions on pediatric asthma during Sahara dust events, in Athens, Greece [21]. There are also data on strong effects of coarse particles on respiratory and of $\mathrm{PM}_{10}$ on cerebrovascular diseases during desert dust outbreaks [37]. Consistent with these results are also the findings of the MED-PARTICLES project that investigated the mortality and the cardiovascular and respiratory hospital admissions in multiple Mediterranean areas between 2001 and 2010. Increases in $\mathrm{PM}_{10}$ were positively associated with increases in mortality and hospital admissions due to cardio-respiratory causes [38]. Thus, in general, the results of morbidity studies provide more consistent indication of associations compared to those investigating the desert dust effects on mortality.

The effects of dust could be attributed to a complex mixture of factors, including the change in the concentration and profile of particles, the lowering of the layer boundary height or/and the transport of pollen or bacteria. We hypothesized that although the greater part of desert dust effects may be attributed to particles' effects there may also be other mechanisms, as for example the lowering of the boundary height may create a more toxic air pollution profile multiplying the effects of various air pollutants. Unfortunately we have no data to test any of these hypotheses. Hence, we consider the dust as an effect modifier for PM mass health effects, and PM separated in two components: one as a mediator of dust effects and another mainly characterized by PM from local emissions as an independent risk factor. However we only have one measurement for the total mass of PM and we can only approach the 2 components by testing the interaction of PM with desert dust days. The proposed associations are schematically depicted in Fig. 1. Unfortunately, lack of data for pollen or particles' components data in the Athens' region for the study period does not allow us to perform further sensitivity analyses.

Our finding of effects on respiratory morbidity during desert dust events, after adjusting for $\mathrm{PM}_{10}$, corroborates the hypothesis that these effects maybe partly attributed to specific biogenic factors and particles' chemical constituents transferred from Africa not captured by measured particles' concentrations [39]. $\mathrm{PM}_{10}$ are a heterogeneous group containing particles of both human and natural sources, hence depending on their chemical composition they may have different toxicity. Thus, apart from the adverse health effect of the particles, desert dust has further characteristics that may result in additional adverse health outcomes. These may be the conveyed metals, microorganisms or other components. The additional toxicity of this mixture that forms the desert dust particles may not be assessed by the global measurement of particles' mass. Further meteorological factors such as wind direction, duration and speed may also modify health outcomes [40]. The exact geographic setting may also play a role: during the course of the dust clouds, the composition of the dust changes due to enrichment with additional elements leading to different chemical mixture and thus health effects [15]. Although these factors seem to provide a reasonable explanation for our findings, this remains speculative considering that some studies observed no or only moderate association of chemical composition with the health effects $[13,41]$.

The $\mathrm{PM}_{10}$ levels in our study showed no relevant difference in days with desert dust outbreaks compared with days without dust outbreaks. This is surprising given the fact that desert dust by itself conveys particulate matter. The only reasonable explanation for this would be a decreased level of particles from human sources in dust days resulting in similar total levels of particles. The selection of control days with the criterion of similar meteorological data may have contributed to this although this remains speculative.

A limitation of our study is that we could not analyze particulate fractions individually, since $\mathrm{PM}_{2.5}$ concentrations were not measured in Athens during the analysis 


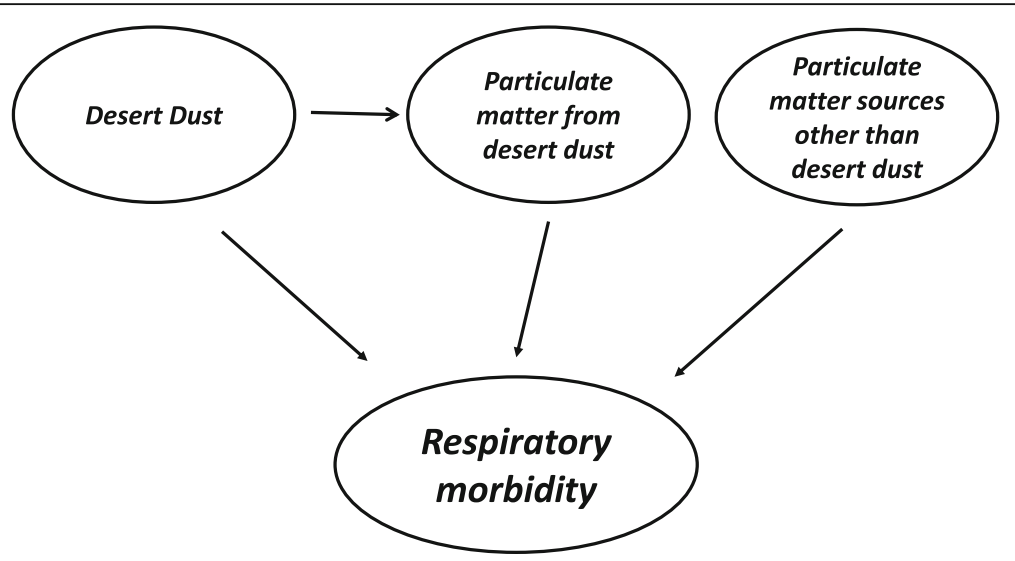

Fig. 1 Directed acyclic graph for the suggested associations between desert dust events, $P M_{10}$ levels and respiratory morbidity. According to the suggested underlying mechanisms, particulate matter has a direct effect on respiratory morbidity. Dust events contribute to the levels of particulate matter and thus affect respiratory morbidity but may also have an effect on respiratory morbidity by other mechanisms independent of the levels of particulate matter

period. However, our results confirm the adverse effects of $\mathrm{PM}_{10}$ from all sources on respiratory morbidity previously identified. Another major limitation is the small sample size that is however partly compensated by the large underlying population and number of counts. This is partly due to our inability to extend the analysis to a longer period because of the lack of electronic records for emergency room visits and of the relevant data for the study periods. This lack of the required IT infrastructure renders an extension of the analysis to a longer time period practically impossible restricting the relevance of our findings.

The observed association of desert dust days and respiratory morbidity was very strong with estimates of approx. $50 \%$ increase in risk of emergency room visits or admissions on dust days compared with the non-dust days. These effects although consistent across all tested strata such as male/female or age below/above 65 years as well as across the different outcomes, are much larger than the effects usually reported in the literature. For this reason, we cannot exclude the possibility of uncontrolled confounding or of a chance finding. However, applying sensitivity analysis, did not modify the magnitude of effects, which remain large.

\section{Conclusions}

In conclusion, days with desert dust transportation were associated with significantly increased emergency room visits and admissions for respiratory disorders such as asthma, COPD and respiratory infections in the metropolitan region of Athens, Greece. This effect was independent of $\mathrm{PM}_{10}$ concentrations and was of a clinically significant magnitude with increases of the different outcomes by $40-50 \%$.

\section{Additional file}

Additional file 1: Supplemental Tables. (DOCX 20 kb)

\section{Abbreviations}

$\mathrm{Cl}$ : Confidence interval; COPD : Chronic obstructive pulmonary disease; ICD: International Statistical Classification of Diseases and Related Health Problems; PM: Particulate matter

\section{Acknowledgements}

We would like to thank Jorge Pey for the provision of the desert dust days identification during our study period based on the characterization criteria applied in Stafoggia et al. 2016.

\section{Funding}

There has been no specific funding by any institution or company for the study.

\section{Availability of data and materials}

The data that support the findings of this study are available from the corresponding author upon reasonable request.

\section{Authors' contributions}

All authors have read and approved the final manuscript. SMT has collected the data, participated in the analysis of the data and drafted the manuscript. ES has performed the analysis of the data, contributed significantly to their interpretation and critically reviewed the manuscript. SR has contributed to the analysis of the data, their interpretation and critically reviewed the manuscript. KK was a major contributor in the conception of the study, the analysis and interpretation of the data and in writing the manuscript. PAS contributed in the interpretation of the data and critically reviewed the manuscript. AK has conceived the study and was a major contributor in analysis and interpretation of the data and in writing the manuscript.

Ethics approval and consent to participate

Data were collected retrospectively be review of medical records. Approval for conduction of the study was acquired from the institutional review boards of all involved hospitals.

Consent for publications

No individual person's data are contained in the manuscript.

Competing interests

The authors declare that they have no competing interests. 


\section{Publisher's Note}

Springer Nature remains neutral with regard to jurisdictional claims in published maps and institutional affiliations.

\section{Author details Greece. \\ Received: 1 December 2016 Accepted: 26 June 2017 \\ Published online: 01 July 2017}

'2nd Department of Pulmonary Medicine, School of Medicine, National and Kapodistrian University of Athens, "ATTIKON" University Hospital, Athens, Greece. ${ }^{2}$ Department of Hygiene, Epidemiology and Medical Statistics, School of Medicine, National and Kapodistrian University of Athens, Athens,

\section{References}

1. Engelstaedter S, Tegen I, Washington R. North African dust emissions and transport. Earth Sci Rev. 2006;79:73-100.

2. Gerasopoulos E, Kouvarakis G, Babasakalis P, Vrekoussis M, Putaud J-P, Mihalopoulos N. Origin and variability of particulate matter $\left(\mathrm{PM}_{10}\right)$ mass concentrations over the eastern Mediterranean. Atmos Environ. 2006;40:4679-90.

3. Matassoni L, Pratesi G, Centioli D, Cadoni F, Lucarelli F, Nava S, et al. Saharan dust contribution to $\mathrm{PM}_{10}, \mathrm{PM}_{2.5}$ and $\mathrm{PM}_{1}$ in urban and suburban areas of Rome: a comparisonbetween single-particle SEM-EDS analysis and wholesample PIXE analysis. J Environ Monit. 2011;13:732-42.

4. Pey J, Querol X, Alastuey A, Forastiere F, Stafoggia M. African dust outbreaks over the Mediterranean Basin during2001-2011: PM10 concentrations, phenomenology and trends, andits relation with synoptic and mesoscale meteorology. Atmos Chem Phys. 2013;13:1395-410.

5. Anderson HR, Atkinson RW, Peacock JL, Sweeting MJ, Marston L. Ambient particulate matter and health effects: publication bias in studies of shortterm associations. Epidemiology. 2005;16:155-63.

6. Atkinson RW, Kang S, Anderson HR, Mills IC, Walton HA. Epidemiological time series studies of $\mathrm{PM}_{2.5}$ and daily mortality and daily admissions: a systematic review and meta-analysis. Thorax. 2014;69:660-5.

7. Brunekreef B, Holgate ST. Air pollution and health. Lancet. 2002;360:1233-42.

8. Karakatsani A, Analitis A, Perifanou D, Ayres JG, Harrison RM, Kotronarou A, et al. Particulate matter air pollution and respiratory symptoms in individuals having either asthma or chronic obstructive pulmonary disease: a European multicentre panel study. Environ Health. 2012;11:75.

9. Moreno T, Querol X, Castillo S, Alastuey A, Cuevas E, Herrmann L, et al. Geochemical variations in aeolian mineral particles from the Sahara- Sahel dust corridor. Chemosphere. 2006;65:261-70.

10. Polymenakou PN, Mandalakis M, Stephanou EG, Tselepides A. Particle size distribution of airborne microorganisms and pathogens during an intense African dust event in the eastern Mediterranean. Environ Health Perspect. 2008;116:292-6.

11. Hervàs A, Camarero L, Reche I, Casamayor EO. Viability and potential for immigration of airborne bacteria from Africa that reach high mountain lakes in Europe. Environ Microbiol. 2009;11:1612-23.

12. Balayiannis GP, Anastassiadis M, Anagnostopoulos H. Endosulfan in windtransported African dust depositions in Crete. Bull Environ ContamToxicol. 2009;83:780-2

13. Pérez L, Tobias A, Querol X, Künzli N, Pey J, Alastuey A, et al. Coarse particles from Saharan dust and daily mortality. Epidemiology. 2008;19:800-7.

14. Sánchez de la Campa A, García-Salamanca A, Solano J, de la Rosa J, Ramos $J$. Chemical and microbiological characterization of atmospheric particulate matter during an intense African dust event in Southern Spain. Environ Sci Technol. 2013;47:3630-8.

15. Karanasiou A, Moreno N, Moreno T, Viana M, de Leeuw F, Querol X. Health effects from Sahara dust episodes in Europe: literature review and research gaps. Environ Int. 2012;47:107-14.

16. Katsouyanni K, Karakatsani A, Messari I, Touloumi G, Hatzakis A, Kalandidi A, et al. Air pollution and cause specific mortality in Athens. J Epidemiol Community Health. 1990:44:321-4.

17. Pantazopoulou A, Katsouyanni K, Kourea-Kremastinou J, Trichopoulos D. Short-term effects of air pollution on hospital emergency out-patient visits and admissions in the greater Athens area. Env Res. 1995;69:31-6.

18. Karakatsani A, Andreadaki S, Katsouyanni K, Dimitroulis I, Trichopoulos D, Benetou $\mathrm{V}$, et al. Air pollution in relation to manifestations of chronic pulmonary disease: a nested case-control study in Athens, Greece. Eur J Epidemiol. 2003;18:45-53.

19. Kallos G, Nickovic S, Papadopoulos A, Jovic D, Kakaliagou O, Misirlis N, et al. The regional weather forecasting system SKIRON: an overview. In: Proceedings of the Symposium on Regional weather Prediction on Parallel Computer Environments, Athens, Greece, 15-17 October 1997, pp. 109-22. https://books.google.de/books/about/Proceedings_of_the_Symposium_on_ Regional.html?id=G7jlcQAACAAJ\&redir_esc =y.

20. Samoli E, Kougea E, Kassomenos P, Analitis A, Katsouyanni K. Does the presence of desert dust modify the effect of PM10 on mortality in Athens, Greece? Sci Total Environ. 2011:409:2049-54.

21. Samoli E, Nastos PT, Paliatsos AG, Katsouyanni K, Priftis KN. Acute effects of air pollution on pediatric asthma exacerbation: evidence of association and effect modification. Environ Res. 2011;111:418-24.

22. Stafoggia M, Zauli-Sajani S, Pey J, Samoli E, Alessandrini E, Basagaña X, et al., MED-PARTICLES Study Group. Desert dust outbreaks in Southern Europe: contribution to daily $\mathrm{PM}_{10}$ concentrations and short-term associations with mortality and hospital admissions. Environ Health Perspect. 2016;124:413-9.

23. Matassoni L, Patesi G, Centioli D, Cadoni F, Malesani P, Caricchia AM, et al. Saharan dust episodes in Italy: influence on PM10 daily limit value (DLV) exceedances and the related synoptic. J Environ Monit. 2009;11:1586-94.

24. Manney S, Meddings CM, Harrison RM, Mansur AH, Karakatsani A, Analitis A, et al. Association between exhaled breath condensate nitrate + nitrite levels with ambient coarse particle exposure in subjects with airway disease. OEM. 2012;69:663-9.

25. Tobías A, Pérez L, Díaz J, Linares C, Pey J, Alastruey A, et al. Short-term effects of particulate matter on total mortality during Saharan dust outbreaks: a case-crossover analysis in Madrid (Spain). Sci Total Environ. 2011;412-413:386-9.

26. Mallone S, Stafoggia M, Faustini A, Gobbi GP, Marconi A, Forastiere F. Saharan dust and associations between particulatematter and dailymortality in Rome, Italy. Environ Health Persp. 2011;119:1409-14.

27. Sajani SZ, Miglio R, Bonasoni P, Cristofanelli P, Marinoni A, Sartini C, et al. Saharan dust and daily mortality in Emilia-Romagna (Italy). Occup Environ Med. 2011;68:446-51.

28. Jiménez E, Linares C, Martínez D, Díaz J. Role of Saharan dust in the relationship between particulate matter and short-term daily mortality among the elderly in Madrid (Spain). Sci Total Environ. 2010;408:5729-36.

29. Ferrari U, Exner T, Wanka ER, Bergemann C, Meyer-Arnek J, Hildenbrand B, et al. Influence of air pressure, humidity, solar radiation, temperature, and wind speed on ambulatory visits due to chronic obstructive pulmonary disease in Bavaria, Germany. Int J Biometeorol. 2012;56:137-43.

30. Liang WM, Liu WP, Kuo HW. Diurnal temperature range and emergency room admissions for chronic obstructive pulmonary disease in Taiwan. Int J Biometeorol. 2009;53:17-23.

31. Mäkinen TM, Juvonen R, Jokelainen J, Harju TH, Peitso A, Bloigu A, et al. Cold temperature and low humidity are associated with increased occurrence of respiratory tract infections. Respir Med. 2009;103:456-62.

32. Mantecca P, Farina F, Moschini E, Gallinotti D, Gualtieri M, Rohr A, et al. Comparative acute lung inflammation induced by atmospheric PM and size-fractionated tire particles. Toxicol Lett. 2010;198:244-54.

33. van Eeden SF, Hogg JC. Systemic inflammatory response induced by particulate matter air pollution: the importance of bone-marrow stimulation. J Toxicol Environ Health A. 2002;65:1597-613.

34. Valavanidis A, Fiotakis K, Vlachogianni T. Airborne particulate matter and human health: toxicological assessment and importance of size and composition of particles for oxidative damage and carcinogenic mechanisms. J Environ Sci Health C Environ Carcinog Ecotoxicol Rev. 2008;26:339-62.

35. Risom L, Møller P, Loft S. Oxidative stress-induced DNA damage by particulate air pollution. Mutat Res. 2005;592:119-37.

36. Middleton N, Yiallouros P, Kleanthous S, Kolokotroni O, Schwartz J, Dockery DW, et al. A 10-year time-series analysis of respiratory and cardiovascular morbidity in Nicosia, Cyprus: the effect of short-term changes in air pollution and dust storms. Environ Health. 2008:7:39.

37. Alessandrini ER, Stafoggia M, Faustini A, Gobbi GP, Forastiere F. Saharan dust and the association between particulate matter and daily hospitalizations in Rome. Italy Occup Environ Med. 2013;70:432-4

38. Stafoggia M, Samoli E, Alessandrini E, Cadum E, Ostro B, Berti G, et al., MEDPARTICLES Study Group. Short-term associations between fine and coarse particulate matter and hospitalizations in Southern Europe: results from the MED-PARTICLES project. Environ Health Perspect. 2013;121:1026-33. 
39. Griffin DW. Atmospheric movement of microorganisms in clouds of desert dust and implications for human health. Clin Microbiol Rev. 2007;20:459-77.

40. Papadopoulou N, Tountas Y, Sypsa V, Katsouyanni K, Analitis A, Kassomenos P. Effect of south winds on daily mortality in Athens. Clim Res. 2009;38:193-8.

41. Basagaña X, Jacquemin B, Karanasiou A, Ostro B, Querol X, Agis D, et al, MED-PARTICLES study group. Short-term effects of particulate matter constituents on daily hospitalizations and mortality in five south-European cities: results from the MED-PARTICLES project. Environ Int. 2015;75:151-8.

Submit your next manuscript to BioMed Central and we will help you at every step:

- We accept pre-submission inquiries

- Our selector tool helps you to find the most relevant journal

- We provide round the clock customer support

- Convenient online submission

- Thorough peer review

- Inclusion in PubMed and all major indexing services

- Maximum visibility for your research

Submit your manuscript at www.biomedcentral.com/submit
Biomed Central 